\title{
STRATEGI PENGEMBANGAN AGROINDUSTRI DODOL SALAK DI DESA PANGU SATU KECAMATAN RATAHAN
}

\author{
Anisa Palit \\ Leonardus R. Rengkung \\ Eyverson Ruauw
}

\begin{abstract}
This research aims to formulate internal and external strategy in developing Dodol Salak agroindustry in Pangu One Village. The study was conducted from March to May 2017 from preparation to the preparation of research reports. The data obtained in this research includes primary and secondary data. Primary data collection was done by interview technique to the respondent while secondary data was obtained by searching in the form of documents from related institution, seminar papers, This study used primary data and secondary data, with literature relevant to the research topic. The analysis used in this research is by using SWOT Analysis method. The results of this study indicate that the right strategy for the development of dolcol agroindustry in Pangu Satu Village, Ratahan Sub-district is to apply aggressive strategy, that is by creating creating process sorting of raw materials and better production equipment and utilizing manpower to produce superior product; through the process of sorting out the selection of good raw materials to increase revenue; companies use products that are free from preservatives and dyes to increase public interest in refined products; improve the process of sorting raw materials and the quality of health products to be more able to compete with existing companies; cooperate not only with one supplier (farmer); increase capital through related institutions such as Bank or other agencies; conducting human resource training to improve the company's work processes and increase opportunities for employers to create new jobs and reduce unemployment; increase capital income to prevent piracy of labor and utilize capital for infrastructure activities and transportation facilities.
\end{abstract}

Keyword: Strategy, Agroindustry Development, SWOT Analysis, Dodol Salak, Kecamatan Ratahan. .

\begin{abstract}
ABSTRAK
Penelitian ini bertujuan untuk merumuskan strategi internal dan eksternal dalam mengembangkan agroindustri Dodol Salak di Desa Pangu Satu. Penelitian ini dilaksanakan dari bulan Maret sampai bulan Mei 2017 mulai dari persiapan sampai penyusunan laporan penelitian. Data yang di peroleh dalam penelitian ini meliputi data primer dan sekunder. Pengumpulan data primer dilakukan dengan teknik wawancara kepada responden sedangkan data sekunder didapat dengan penelusuran berupa dokumen dari instansi yang terkait, makalah-makalah seminar, Penelitian ini menggunakan data primer dan data sekunder, dengan literatur yang relevan dengan topik penelitian. Analisis yang digunakan dalam penelitian ini yaitu dengan menggunakan metode Analisis SWOT. Hasil penelitian ini menunjukkan bahwa strategi yang tepat untuk pengembangan agroindustri dodol salak di Desa Pangu Satu Kecamatan Ratahan adalah dengan menerapkan strategi agresif, yaitu dengan menciptakan menciptakan proses sortiran bahan baku dan peralatan produksi yang lebih baik serta memanfaatkan tenaga kerja untuk menghasilkan produk yang unggul; melalui proses sortir pemilihan bahan baku yang baik untuk meningkatkan pendapatan; perusahaan menggunakan produk yang bebas dari bahan pengawet dan pewarna untuk meningkatkan minat masyarakat terhadap produk olahan; meningkatkan proses sortir bahan baku dan kualitas kesehatan produk untuk lebih dapat bersaing dengan perusahaan yang ada; bekerjasama bukan hanya dengan satu pemasok (petani); menambah modal melalui instansi-instansi terkait seperti Bank atau instansi lainnya; mengadakan pelatihan sumberdaya manusia untuk meningkatkan proses kerja perusahaan dan menambah peluang bagi pengusaha untuk menciptakan lapangan kerja baru dan mengurangi angka pengangguran; meningkatkan pendapatan modal untuk mencegah terjadinya pembajakan tenaga kerja dan memanfaatkan modal untuk kegiatan prasarana dan sarana transportasi.
\end{abstract}

Kata Kunci: Strategi, Pengembangan Agroindustri, Analisis SWOT, Dodol Salak, Kecamatan Ratahan. 


\section{PENDAHULUAN}

\section{Latar Belakang}

Sektor pertanian hingga saat ini masih tetap menjadi tumpuan pertumbuhan ekonomi daerah Provinsi Sulawesi Utara. Pendapatan sebagian besar masyarakat didaerah ini masih sangat tergantung pada sektor pertanian yaitu melibatkan sekitar 50-60\% dari tenaga kerja yang tersedia. Kontribusi sektor ini terhadap PDRB selang 5 tahun terakhir sekitar 25-30\%, memberi indikasi bahwa pengelolaan sumberdaya pada sektor ini dibandingkan dengan sektor lain belum optimal, disebabkan antara lain karena andalan nilai ekonominya masih terfokus pada produk primer dengan sistem pengelolaan usahatani umumnya masih secara tradisional (Sondakh, 2008). Beberapa aspek penting yang perlu dicermati dalam pengembangan pertanian di Sulawesi Utara yaitu melanjutkan kajian kinerja pengembangan pertanian yang mencakup pertumbuhan sektor pertanian yang lebih difokuskan pada pembenahan sistem agribisnis komoditas unggulan dan andalan daerah. Berbagai hasil kajian menginformasikan bahwa dalam sistem agribisnis selama ini telah terjadi sistem dan tatanan yang tidak proporsional yaitu adanya perlakuan eksploitasi diantara pelaku dalam sistem agribisnis, terutama pihak petani sebagai pelaku utama selalu dalam kondisi tidak berdaya (Sondakh, 2008).

Pertanian adalah kegiatan pemanfaatan sumber daya hayati yang dilakukan manusia untuk menghasilkan bahan pangan, bahan baku industri, atau sumber energi, serta untuk mengelola lingkungan hidupnya. Kegiatan pemanfaatan sumber daya hayati yang termasuk dalam pertanian biasa difahami orang sebagai budidaya tanaman atau bercocok tanam (crop cultivation) serta pembesaran hewan ternak (raising),meskipun cakupannya dapat pula berupa pemanfaatan mikroorganisme dan bioenzim dalam pengolahan produk lanjutan, seperti pembuatan keju dan tempe, atau sekedar ekstraksi semata, seperti penangkapan ikan atau eksploitasi hutan. Sektor pertanian merupakan sektor yang mempunyai peranan strategis dalam struktur pembangunan perekonomian nasional. Indonesia dikenal sebagai Negara agraris yang berarti Negara yang mengandalkan sektor pertanian baik sebagai sumber mata pencaharian maupun sebagai penopang pembangunan. Sektor pertanian meliputi subsektor tanaman bahan makanan, subsektor hortikultura, subsektor perikanan, dan subsektor peternakan. Hortikultura merupakan salah satu sub sektor dalam sektor pertanian yang yang berpotensi untuk dikembangkan karena memiliki nilai ekonomis yang cukup tinggi. Indonesia memiliki aneka produk hortikultura, dengan ragam plasma nutfah dan varietas yang memungkinkan bagi upaya pengembangan buah, sayuran dan bunga.

Subsektor hortikultura buah-buahan termasuk salak, merupakan salah satu bidang yang memberikan kontribusi bagi perekonomian Sulawesi Utara. Dari tahun ke tahun menunjukan peningkatan sehingga pemerintah memberikan perhatian terhadap pengembangan subsektor tersebut. Salak merupakan salah satu komoditas yang dapat dikembangkan karena potensinya yang baik untuk agribisnis dan agroindustri yang telah memberikan dampak positif terhadap pendapatan petani karena selain dimakan sebagai buah segar salak juga dapat diolah menjadi berbagai produk olahan yang dikemas semenarik mungkin sehingga dapat dapat menambah nilai ekonomi bagi petani salak. Selain itu, buah salak juga merupakan sumber vitamin dan mineral yang baik bagi tubuh (Darmadi, 2001 dalam Manurung, dkk, 2008).

Keberadaan salak yang berlimpah pada musim panen raya dan harga menjadi sangat murah memunculkan kreasi masyarakat Pangu untuk mengolah buah salak segar menjadi berbagai macam produk olahan diantaranya dodol salak. Dengan adanya kemauan yang keras walaupun dengan pengetahuan yang minim tentang cara pembuatan dodol salak, mereka bisa menjalani usaha pembuatan dodol salak menjadi sebuah usaha kecil. Melalui usaha pengolahan dodol salak tersebut maka didirikan sebuah usaha di Desa Pangu Satu yang dinamakan "UD Mandiri" dan digolongkan dalam bentuk usaha mikro, kecil dan menengah. Pengolahan hasil pertanian dodol salak "UD Mandiri" merupakan suatu usaha rumah tangga yang beroperasi sejak tahun 2006 yang terletak di Kecamatan Ratahan, tepatnya di Desa Pangu Satu. Kegiatan "UD Mandiri" dikabupaten Minahasa Tenggara mempunyai peran penting dalam pembangunan 
ekonomi masyarakat Pangu, karena dapat memanfaatkan hasil salak yang berlimpah menjadi dodol salak yang mempunyai nilai tambah serta banyak menyerap tenaga kerja disekitarnya. Kegiatan "UD Mandiri" menjadi wadah yang baik bagi penciptaan lapangan pekerjaan yang produktif dan merupakan usaha yang bersifat padat karya, tidak membutuhkan persyaratan tertentu seperti tingkat pendidikan, keahlian atau keterampilan pekerja, dan penggunaan modal usaha relatif sedikit serta teknologi yang digunakan cenderung sederhana. Kegiatan "UD Mandiri" dodol salak merupakan kegiatan ekonomi rakyat yang berskala kecil dengan bidang usaha yang secara mayoritas merupakan kegiatan usaha kecil dan perlu dilindungi untuk mencegah dari persaingan usaha yang tidak sehat. Pengembangan usaha UD Mandiri di Desa Pangu harus lebih diarahkan untuk meningkatkan kemampuan menjadi usaha menengah. Perkembangan dodol salak di Desa Pangu tidak lepas dari berbagai macam masalah dan hambatan seperti kurangnya modal, manajemen yang kurang terkoordinasi dan lain-lain, maka dari itu diperlukan strategistrategi dalam pengembangan agroindustri untuk mengatasi masalah dan hambatan tersebut. Strategi merupakan seni memadukan atau menginteraksikan antara faktor kunci keberhasilan agar terjadi sinergi dalam mencapai tujuan dan merupakan sarana untuk mencapai tujuan. Manfaat strategi adalah untuk mengoptimalkan sumberdaya unggulan dalam memaksimalkan pencapaian sasaran kinerja. Dalam konsep manajemen cara terbaik untuk mencapai tujuan, sasaran dan kinerja adalah dengan strategi memberdayakan sumber daya secara efektif dan efesien (LAN-RI,2008). Agroindustri merupakan kegiatan yang memanfaatkan hasil pertanian secara umum yang meliputi (Pertanian, Peternakan, Perikanan, dan Kehutanan) sebagai bahan baku, merancang dan menyediakan peralatan serta jasa untuk kegiatan produk yang mempunyai nilai jual ekonomis.Usaha dodol salak dibuat karena melihat panen salak di desa Pangu pada bulan Oktober rata-rata mencapai dua ton dalam seminggu sedangkan pada Februari-Maret bisa mencapai 15-20 ton seminggu. Dari jumlah tersebut, diamati lebih dari $500 \mathrm{~kg}$ buah salak terbuang per bulannya karena tidak bisa masuk ke supermarket. Maka dari itu, agroindustri "UD Mandiri" memutar otak agar "sampah" salak yang tidak bisa dijual ke supermarket ini tetap memiliki nilai jual dengan cara mengolahnya menjadi dodol salak.

\section{Perumusan Masalah}

Berdasarkan latar belakang, maka yang menjadi perumusan masalah dalam penelitian ini yaitu: Bagaimana strategi pengembangan yang dapat diterapkan dalam pengembangan agroindustri Dodol Salak di Desa Pangu Satu Kecamatan Ratahan?

\section{Tujuan Penelitian}

Tujuan penelitian ini yaitu: Untuk merumuskan strategi internal dan eksternal dalam mengembangkan agroindustri Dodol Salak di Desa Pangu Satu.

\section{Manfaat Penelitian}

Adapun manfaat dari penelitan ini yaitu

1. Sebagai tambahan pengetahuan bagi penulis dalam bentuk karya tulis ilmiah

2. Sebagai bahan referensi bagi pihak lain yang memerlukan untuk dijadikan bahan perbandingan untuk penelitian selanjutnya

\section{METODOLOGI PENELITIAN}

\section{Waktu dan Tempat Penelitian}

Penelitian ini dilaksanakan selama 3 bulan yaitu dari bulan Maret sampai dengan Mei 2017 dan mengambil lokasi di Desa Pangu Satu Kecamatan Ratahan.

\section{Metode Pengumpulan Data}

Data yang digunakan dalam penelitian ini menggunakan data Primer dan data Sekunder, dimana data Primer didapat dari wawancara langsung kepada pihak respoden. Data Sekunder di dapat dari Instansi-instansi yang terkait.

\section{Konsep Pengukuran Variabel}

Terdapat dua faktor variabel yang akan diukur dalam penelitian ini, yaitu faktor internal dan faktor eksternal. Adapun faktor internal meliputi kekuatan dan kelemahan (Strengths and Weakness), faktor eksternal meliputi peluang dan ancaman (Opportunities and Threats ). 


\section{Metode Analisis Data}

Metode analisis data yang digunakan dalam penelitian ini adalah metode analisis SWOT dengan tahap-tahap sebagai berikut:

\section{Matriks IFAS dan EFAS}

Matriks IFAS digunakan untuk mengidentifikasi faktor-faktor internal dan mengklasifikasikannya menjadi kekuatan dan kelemahan usaha yang akan dijalankan, kemudian dilakukan pembobotan dan peratingan. Sama halnya dengan matriks EFAS, yaitu untuk menganalisis faktor-faktor eksternal dan mengklasifikasikannya menjadi peluang dan ancaman bagi usaha agroindustri yang akan dijalankan. Berikut adalah cara-cara penentuan Faktor Strategi Eksternal:

a) Susunlah dalam kolom 1 (5 sampai dengan 10 peluang dan ancaman).

b) Beri bobot masing-masing faktor dalam kolom 2, mulai dari 1,0 (sangat penting) sampai dengan 0,0 (tidak penting). Faktorfaktor tersebut kemungkinan dapat memberikan dampak terhadap faktor strategis.

c) Hitung rating (dalam kolom 3) untuk masing-masing faktor dengan memberikan skala mulai dari 4 (outstanding) sampai dengan 1 (poor) berdasarkan pengaruh faktor tersebut terhadap kondisi perusahaan yang bersangkutan. Pemberian nilai rating untuk faktor peluang bersifat positif (peluang yang semakin besar diberi rating +4 , tetapi jika peluangnya kecil, diberi rating +1). Pemberian nilai rating ancaman adalah kebalikannya. Misalnya, jika nilai ancamannya sangat besar, ratingnya adalah 1. Sebaliknya, jika nilai ancamannya sedikit ratingnya 4.

d) Kalikan bobot pada kolom 2 dengan rating pada kolom 3, untuk memperoleh faktor pembobotan dalam kolom 4. Hasilnya berupa skor pembobotan untuk masingmasing faktor yang nilainya bervariasi mulai dari 4,0 (outstanding) sampai dengan 1,0 (poor).

e) Gunakan kolom 5 untuk memberikan komentar atau catatan mengapa faktorfaktor tertentu dipilih dan bagaimana skor pembobotannya dihitung.

f) Jumlahkan skor pembobotan (pada kolom 4), untuk memperoleh total skor pembobotan bagi perusahaan yang bersangkutan. Nilai total ini menunjukkan bagaimana perusahaan tertentu bereaksi terhadap faktor-faktor strategis eksternalnya. Total skor ini dapat digunakan untuk membandingkan perusahaan ini dengan perusahaan lainnya dalam kelompok industri yang sama.

Selanjutnya berikut adalah cara-cara penentuan Faktor Strategi Internal:

a) Tentukan faktor-faktor yang menjadi kekuatan serta kelemahan perusahaan dalam kolom 1.

b) Beri bobot masing-masing faktor tersebut dengan skala mulai dari 1,0 (paling penting) sampai dengan 0,0 (tidak penting), berdasarkan pengaruh faktor-faktor tersebut terhadap posisi strategis perusahaan. (Semua bobot tersebut jumlahnya tidak boleh melebihi skor total $1,00)$.

c) Hitung rating (dalam kolom 3) untuk masing-masing faktor dengan memberikan skala mulai dari 4 (outstanding) sampai dengan 1 (poor), berdasarkan pengaruh faktor tersebut terhadap kondisi perusahaan yang bersangkutan. Variabel yang bersifat positif (semua variabel yang masuk kategori kekuatan) diberi nilai mulai dari +1 sampai dengan +4 (sangat baik) dengan membandingkannya dengan rata-rata industri atau dengan pesaing utama. Sedangkan variabel yang bersifat negatif, kebalikannya. Contohnya, jika kelemahan perusahaan besar sekali dibandingkan dengan rata-rata industri, nilainya adalah 1 , sedangkan jika kelemahan perusahan dibawah rata-rata industri, nilainya adalah 4.

d) Kalikan bobot pada kolom 2 dengan rating pada kolom 3, untuk memperoleh faktor pembobotan dalam kolom 4. Hasilnya berupa skor pembobotan untuk masingmasing faktor yang nilainya bervariasi mulai dari 4,0 (outstanding) sampai dengan 1,0 (poor).

e) Gunakan kolom 5 untuk memberikan komentar atau catatan mengapa faktorfaktor tertentu dipilih, dan bagaimana skor pembobotannya dihitung.

f) Jumlahkan skor pembobotan (pada kolom 4), untuk memperoleh total skor 
pembobotan bagi perusahaan yang bersangkutan. Nilai total ini menunjukkan bagaimana perusahaan tertentu bereaksi terhadap faktor-faktor strategis eksternalnya. Total skor ini dapat digunakan untuk membandingkan perusahaan ini dengan perusahaan lainnya dalam kelompok industri yang sama.

Untuk bobot setiap variabel diperoleh dengan menentukan nilai setiap variabel terhadap jumlah nilai keseluruhan variabel dengan menggunakan rumus (Kesatria, 2002):

Keterangan rumus:

$$
\alpha i=\frac{x i}{\sum_{i=1}^{n} x i}
$$

$$
\begin{aligned}
\alpha i & =\text { bobot variabel ke- } \mathrm{i} \\
x i & =\text { nilai variabel ke-i } \\
i & =1,2,3, \ldots . . \\
\mathrm{n} & =\text { jumlah variabel }
\end{aligned}
$$

\section{Matriks Analisis SWOT}

Selanjutnya, mengumpulkan informasi yang berpengaruh terhadap kelangsungan pengembangan usaha, yaitu dengan memanfaatkan informasi tersebut ke dalam rumusan strategi. Alat yang digunakan untuk menyusun faktor-faktor strategis usaha adalah matriks SWOT. Matriks SWOT yng dibuat akan menggambarkan bagaimana peluang dan ancaman eksternal digabungkan dengan kekuatan dan kelemahan pada agroindustri dodol salak di Desa Pangu Satu. Sehingga akan menghasilkan suatu rumusan strategi pengembangan usaha. Rumusan strategi ini akan menghasilkan empat alternatif strategi, yaitu strategi kekuatan dan peluang (strategi SO), kelemahan dan peluang (strategi W-O), kekuatan dan ancaman (strategi S-T), serta strategi kelemahan dan ancaman (strategi WT).

1) Strategi $S O$;

Strategi ini dibuat berdasarkan jalan pikiran perusahaan yaitu dengan memanfaatkan seluruh kekuatan untuk merebut dan memanfaatkan peluang dengan sebesar-besarnya.

2) Strategi $S T$;

Strategi ini dilakukan untuk menggunakan kekuatan yang dimiliki untuk mengatasi ancaman yang ada.
3) Strategi $W O$;

Strategi ini dilaksanakan berdasarkan pemanfaatan peluang yang ada dengan cara meminimalkan kelemahan yang ada.

4) Strategi $W T$;

Strategi ini didasarkan pada kegiatan yang bersifat defensive dan berusaha meminimalkan kelemahan yang ada serta menghindari ancaman.

\section{Matriks Grand Strategy (Matriks Posisi)}

Setelah matriks IFAS dan matriks EFAS dibentuk melalui pemilihan sejumlah alternatif strategi dan pemilihan strategi terbaik yang sesuai dengan lingkungan internal dan lingkungan eksternal, selanjutnya depetakan pada matriks posisi (Grand Strategy) dengan menjelaskan setiap sudut dan kuadrannya, yaitu;

a) Sumbu horizontal $(\mathrm{x})$ menunjukan kekuatan dan kelemahan, sedangkan sumbu vertikal (y) menunjukan peluang dan ancaman

b) Posisi perusahaan akan ditentukan oleh hasil sebagai berikut.

1) Jika peluang lebih besar daripada ancaman maka nilai $y>0$ dan sebaliknya kalau ancaman lebih besar daripada peluang maka nilainya $\mathrm{y}<0$.

2) Jika kekuatan lebih besar daripada kelemahan maka nilai $\mathrm{x}>0$, begitu sebaliknya jika kelemahan lebih besar dari kekuatan, maka nilai $\mathrm{x}<0$.

Adapun penjelasan dari masing-masing kuadran pada mariks grand strategy adalah sebagai berikut.

Kuadran I : ini merupakan situasi yang sangat menguntungkan. Perusahaan tersebut memiliki peluang dan kekuatan sehingga dapat memanfaatkan peluang yang ada. Strategi yang harus diterapkan dalam kondisi ini adalah mendukung kebijakan pertumbuhan yang agresif (growth oriented strategy).

Kuadran II : meskipun menghadapi berbagai ancaman, perusahaan 
ini masih memiliki kekuatan dari segi internal.

Kuadran III : perusahaan menghadapi peluang pasar yang sangat besar, tetapi di lain pihak, ia menghadapi beberapa kendala atau kelemahan internal.

Kuadran IV : ini merupakan situasi yang sangat tidak menguntungkan, perusahaan tersebut menghadapi berbagai ancaman dan kelemahan internal.

\section{HASIL DAN PEMBAHASAN}

\section{Deskripsi Usaha Agroindustri Dodol Salak di Kecamatan Ratahan}

Pengolahan hasil pertanian dodol salak "UD Mandiri" merupakan suatu usaha rumah tangga yang beroperasi sejak tahun 2006 dan berlokasi di kecamatan Ratahan Timur, tepatnya di Desa Pangu Satu. Usaha ini telah memproduksi dodol salak selama kurang lebih 10 tahun masa berdirinya dengan menghasilkan rasa khas Minahasa yang berbeda dengan daerah lain. Dalam proses produksi dibutuhkan bahan baku sekitar $10 \mathrm{Kg}$ buah salak segar dengan hasil produksi sebanyak 400 kemasan plastik mika dan daun janur (woka).

Untuk menghasilkan produk dodol salak yang berkualitas baik, perlu adanya ketelitian dalam penanganan pemilihan bahan baku yang tepat. Dengan bercirikan karakteristik rasa buah yang tidak sepat, sisik tampak lebih renggang, aroma buah kuat, tidak ada duri-duri kecil pada permukaan kulit buah, warna daging buah cokelat muda, tekstur buah agak lunak, mudah terlepas dari tandan, dan buahnya tidak busuk. Harga yang diberikan untuk produk dodol salak ini yaitu hanya berkisar Rp. 8.000, dengan jumlah isi kemasan yang berbeda yakni 10 potong dan 12 potong dodol salak. Dodol kemasan isi 12 tiap potongnya dibungkus dengan plastik, sedangkan dodol kemasan isi 10 tiap potongnya dibungkus dengan daun janur (woka) yang dikenal sebagai daun khas Minahasa.

Proses pengolahan produk dodol salak "UD Mandiri" memiliki durasi penanganan produksi sekitar 5 jam, yaitu dari tahap awal hingga finishing yang dimulai dari jam delapan pagi hingga jam dua belas siang. Hal ini dilakukan untuk mengefektif waktu penanganan pengerjaan, dikarenakan banyaknya bahan baku yang harus di produksi. Sedangkan untuk tenaga kerja pada usaha agroindustri ini adalah berjumlah sepuluh orang. Diantaranya, empat tenaga kerja perempuan dan enam tenaga kerja laki-laki yang merupakan tenaga kerja lokal dari daerah usaha tersebut.

\section{Produksi Dodol Salak}

Kegiatan produksi merupakan suatu proses kegiatan yang mengubah bahan baku menjadi bahan jadi atau bahan setengah jadi dan dapat memberikan nilai tambah bagi pelakunya baik untuk kebutuhan konsumsi atau penghasilannya. Dalam kegiatan produksi pengolahan dodol salak, tentunya membutuhkan proses yang tidak instant, dimana pada setiap tahap pembuatannya diperlukan control yang maksimal mulai dari tahap pengadaan bahan baku sampai dengan tahap akhir atau packing dan pemasaran.

\section{Bahan Baku}

Bahan baku yang digunakan dalam memproduksi dodol salak yaitu buah salak segar. Akan tetapi oleh industry pengolahan hasil dodol salak "UD Mandiri" dalam memproduksi dodol salak memilih untuk memperhatikan beberapa hal terkait penggunaan bahan baku buah salak yaitu dengan memiliki karakteristik daging buah berwarna cokelat muda, tekstur buah agak lunak, dan intinya buah salak tidak busuk.

\section{Peralatan dan Mesin}

Dalam memproduksi dodol salak, pemilik usaha masih menggunakan cara tradisional dalam proses produksi. Hal ini dikarenakan, minimnya modal usaha serta kurangnya pengetahuan dan pengoperasian akan teknologi pasca panen dan produksi. Selain itu juga, pemilik masih memilih untuk menggunakan cara dan alat sederhana, untuk mendapatkan rasa dan bentuk produk yang alami.

\section{Tenaga Kerja}

Untuk menjalankan suatu proses produksi perlu adanya tenaga kerja yang terampil dan berpengalaman untuk mempermudah dan 
mengefektifitas waktu pekejaan. Terdapat sepuluh orang tenaga kerja pada usaha pengolahan hasil pertanian dodol salak "UD Mandiri", yaitu enam orang perempuan dan tiga orang laki-laki yang merupakan pekerja tetap dari dalam industri itu sendiri.

Dalam memiih tenaga kerja tetap, pemilik usaha tidak begitu peduli akan status pendidikan, akan tetapi lebih menekankan pada pengalaman, keterampilan dan kreatifitas para pekerjanya. Untuk pembagian pekerjaan, oleh usaha ini masih menggunakan sistem bekerjasama yaitu saling melengkapi anatara pekerja yang satu dengan pekerja yang lainnya, dalam artian bahwa setiap pekerja dapat merangkap semua jenis pekerjaan yang telah di tetapkan. Adapun biaya untuk tenaga kerja pada usaha ini adalah adalah sebesar Rp. 500.000 dalam sekali memproduksi dodol salak.

\section{Proses Produksi}

Dalam melakukan proses produksi pengolahan hasil dodol salak "UD Mandiri" memiliki tahapan yang sama dengan proses membuat dodol pada umumnya tapi bedanya disini kita menggunakan buah salak. Proses produksi pembuatan dodol salak "UD Mandiri" yaitu pertama-tama mengupas salak, mengeluarkan bijinya, lalu daging salak dihaluskan menggunakan blender, kemudian disatukan dengan adonan gula aren dan gula putih. Pada saat yang bersamaan air perasan kelapa dipanaskan dalam kuali besar berdiameter $80 \mathrm{~cm}$ hingga menjadi minyak kelapa. Setelah air perasan kelapa berubah menjadi minyak kelapa, dinginkan sebentar lalu adonan salak dimasukkan ke dalam kuali. Diaduk hingga tercampur dan mengental selama tiga jam. Setelah selesai, dibiarkan hingga agak dingin dan siap untuk dipotong kecil-kecil dan dikemas. Ukuran dodol salak ini panjangnya sekitar $5 \mathrm{~cm}$ dengan diameter $1,5 \mathrm{~cm}$. Dalam proses pengemasan dodol salak dibagi dua, yakni dodol kemasan 10 potong dan dodol kemasan 12 potong dan dibungkus dengan plastik dan daur janur (woka).

\section{Pemasaran}

Pendapatan diperoleh dari hasil penjualan produk yang dihasilkan oleh suatu usaha. Dalam agroindustri, pemasaran produk merupakan hal utama yang harus diperhatikan oleh setiap pemilik usaha, agar diperoleh pendapatan optimal sesuai dengan yang diinginkan. Salah satu hal yang harus diperhatikan dalam memasarkan produk yaitu : kualitas produk, tempat pemasaran, harga produk, dan promosi.

\section{Produk (Product)}

Produk merupakan salah satu bagian dari bauran pemasaran yang dihasilkn maupun ditawarkan oleh perusahaan kepada konsumen. Pengolahan hasil dodol salak "UD Mandiri" memiliki dua produk varian bentuk kemasan unggulan, yaitu dodol kemasan isi 12 tiap potongnya dibungkus dengan plastik dan dodol kemasan isi 10 dibungkus dengan daun janur (woka). Walaupun dengan bahan produksi yang sedikit berbeda, namun diharapkan dengan adanya dua varian bentuk kemasan ini dapat membuat para konsumen dodol, terkhusus konsumen dodol salak usaha milik pengolahan hasil dodol salak "UD Mandiri" ini dapat merasakan kepuasan, baik dari segi rasa, tekstur maupun pelayanan.

2. Tempat (Place)

Dalam sebuah kegiatan pemasaran, tempat yang strategis untuk melakukan proses pemasaran merupakan hal penting yang harus diperhatikan oleh setiap pengusaha. Tempat atau Distribusi mencakup mulai dari sistem transportasi dari perusahaan dalam mengekspor barang, penyimpanan barang, dan pemilihan saluran distribusi.

Usaha pengolahan hasil dodol salak "UD Mandiri" umumnya melakukan pemasaran produknya ke kios, toko oleh-oleh, supermarket, dengan jangkauan pasar hingga ke daerah Tomohon, Manado, dan Ternate. Target pemasaran yaitu semua kalangan, meliputi anak-anak, remaja, dewasa, bahkan lansia.

\section{Harga (Price)}

Harga merupakan nilai yang ada pada suatu produk yang ditawarkan oleh perusahaan. Dalam memasarkan produk olahannya, usaha pengolahan hasil dodol salak "UD Mandiri" memberikan harga untuk setiap satu kemasan dodol salak dengan harga Rp. 8.000. Ini merupakan hal yang sama yang diberlakukan untuk semua jenis pelanggannya dalam memberikan harga.

\section{Promosi (Promotion)}

Menurut Danang (2013), promosi perlu dilakukan agar produk lebih dikenal dan produk bisa bersaing dengan produk sejenis yang 
dihasilkan agroindustri lainnya. Promosi adalah suatu kegiatan yang dilakukan perusahaan agar produk yang ditawarkan oleh perusahaan dapat dikenal oleh masyarakat luas.. Promosi yang dilakukan oleh usaha ini awalnya hanya melalui iklan di Radio. Seiring berjalannya waktu, penjualan produk melalui radio sudah lancar dan dikenal di kalangan masyarakat Sulawesi Utara, kemudian promosi dilanjutkan diluar daerah dengan melalui pameran.

\section{Analisis SWOT Sebagai Alat Formulasi} Strategi Pengembangan Agroindustri Dodol Salak di Desa Pangu Satu

\section{1) Kekuatan}
a) Proses sortir bahan baku yang baik
b) Peralatan produksi yang baik
c) Tenaga kerja perusahaan yang cukup tersedia
d) Produk bebas dari bahan pengawet dan pewarna

2) Kelemahan
a) Terbatasnya modal
b) Manajemen yang kurang terkoordinasi
c) Sumberdaya manusia (SDM) belum terlatih
d) Tingkat kedisiplinan tenaga kerja rendah

3) Peluang
a) Minat masyarakat terhadap produk olahan meningkat
b) Adanya pendapatan dari usaha dodol salak
c) Pangsa pasar yang masih luas
d) Penciptaan lapangan kerja

4) Ancaman
a) Ketersediaan bahan baku yang berfluktuasi
b) "Pembajakan" tenaga kerja
c) Adanya pesaing baru
d) Sarana dan prasarana transportasi yang kurang memadai

\section{Analisis Faktor Internal}

Analisis faktor internal merupakan hasil dari identifikasi faktor internal seperti kekuatan dan kelemahan yang berpengaruh terhadap "UD Mandiri". Penentuan bobot dan rating diperoleh dari empat orang responden dengan cara mengisi kuisioner, sedangkan skor diperoleh dengan mengalikan bobot dan rating.
Tabel 6. Internal Strategic Factors Analysis Summary (IFAS)

\begin{tabular}{|c|c|c|c|c|}
\hline No & Kekuatan & Bobot & Rating & Skor \\
\hline 1 & $\begin{array}{l}\text { Proses sortir } \\
\text { bahan baku yang } \\
\text { baik }\end{array}$ & 0.148 & 4.00 & 0.592 \\
\hline 2 & $\begin{array}{l}\text { Peralatan } \\
\text { produksi yang } \\
\text { baik }\end{array}$ & 0.148 & 3.75 & 0.555 \\
\hline 3 & $\begin{array}{l}\text { Tenaga kerja } \\
\text { yang cukup } \\
\text { tersedia }\end{array}$ & 0.137 & 4.00 & 0.548 \\
\hline 4 & $\begin{array}{l}\text { Produk bebas dari } \\
\text { bahan pengawet } \\
\text { dan pewarna }\end{array}$ & 0.169 & 3.75 & 0.633 \\
\hline & Jumlah Kekuatan & & & 2.328 \\
\hline No & Kelemahan & Bobot & Rating & Skor \\
\hline 1 & $\begin{array}{l}\text { Terbatasnya } \\
\text { modal }\end{array}$ & 0.094 & 1.75 & 0.164 \\
\hline 2 & $\begin{array}{l}\text { Manajemen yang } \\
\text { kurang } \\
\text { terkoordinasi }\end{array}$ & 0.116 & 1.50 & 0.174 \\
\hline 3 & $\begin{array}{l}\text { Sumberdaya } \\
\text { manusia (SDM) } \\
\text { belum terlatih }\end{array}$ & 0.094 & 2.00 & 0.188 \\
\hline 4 & $\begin{array}{l}\text { Tingkat } \\
\text { kedisiplinan } \\
\text { tenaga kerja } \\
\text { rendah }\end{array}$ & 0.094 & 1.75 & 0.164 \\
\hline & $\begin{array}{l}\text { Jumlah } \\
\text { Kelemahan }\end{array}$ & & & 0.690 \\
\hline & $\begin{array}{l}\text { Total Kekuatan } \\
\text { dan Kelemahan }\end{array}$ & 1.000 & & 3.018 \\
\hline
\end{tabular}

Skor Kekuatan - Kelemahan $=2.328-0.690=$ 1.638

Sumber : Hasil Analisis Data IFAS 2017

Tabel enam menunjukkan bahwa produk bebas dari bahan pengawet dan pewarna merupakan kekuatan utama dari "UD Mandiri" dengan nilai skor 0,633 yang berarti kekuatan paling penting dalam perusahaan. Sedangkan terbatasnya modal dan tingkat kedisiplinan tenaga kerja rendah merupakan kelemahan utama dari "UD Mandiri" dengan nilai skor sama yakni 0,164 . 


\section{Analisis Faktor Eksternal}

Analisis faktor eksternal merupakan hasil dari identifikasi faktor eksternal seperti peluang dan ancaman yang berpengaruh terhadap "UD Mandiri". Penentuan bobot dan rating diperoleh dari empat orang responden dengan cara mengisi kuisioner, sedangkan skor diperoleh dengan mengalikan bobot dan rating. Berikut adalah matriks EFAS UD Mandiri :

Tabel 7. Eksternal Strategic Factors Analysis Summary (EFAS)

\begin{tabular}{ccccc}
\hline No & \multicolumn{1}{c}{ Peluang } & Bobot & Rating & Skor \\
\hline 1 & $\begin{array}{l}\text { Minat } \\
\text { masyarakat } \\
\text { terhadap produk } \\
\text { olahan } \\
\text { meningkat } \\
2\end{array}$ & 0.173 & 4.00 & 0.692 \\
$\begin{array}{l}\text { Adanya } \\
\text { pendapatan dari } \\
\text { usaha dodol } \\
\text { salak 0.140 }\end{array}$ & & & \\
3 & $\begin{array}{l}\text { Pangsa pasar } \\
\text { yang masih luas }\end{array}$ & 0.151 & 3.50 & 0.490 \\
4 & $\begin{array}{l}\text { Penciptaan } \\
\text { lapangan kerja }\end{array}$ & 0.151 & 3.75 & 0.566 \\
\hline & Jumlah Peluang & & 2.201 \\
\hline
\end{tabular}

\begin{tabular}{clccc}
\hline No & \multicolumn{1}{c}{ Ancaman } & Bobot & Rating & Skor \\
\hline 1 & $\begin{array}{l}\text { Ketersediaan } \\
\text { bahan baku yang } \\
\text { berfluktuasi }\end{array}$ & 0.086 & 1.25 & 0.107 \\
2 & $\begin{array}{l}\text { Pembajakan } \\
\text { tenaga kerja }\end{array}$ & 0.096 & 1.50 & 0.144 \\
3 & $\begin{array}{l}\text { Adanya pesaing } \\
\text { baru }\end{array}$ & 0.107 & 2.00 & 0.214 \\
4 & $\begin{array}{l}\text { Sarana dan } \\
\text { prasarana } \\
\text { transportasi yang } \\
\text { kurang memadai }\end{array}$ & 0.096 & 1.50 & \\
\hline & Jumlah Ancaman & & & 0.609 \\
\hline & $\begin{array}{l}\text { Total Peluang } \\
\text { dan Ancaman }\end{array}$ & 1.000 & & 2.810 \\
\hline
\end{tabular}

Skor Peluang - Ancaman $=2.201-0.609=1.592$

Sumber : Hasil Analisis Data EFAS 2017

Tabel 7 menunjukkan bahwa minat masyarakat terhadap produk olahan meningkat menjadi peluang utama dari "UD Mandiri" karena memiliki skor 0,692. Penciptaan lapangan kerja juga menjadi peluang bagi perusahaan karena memiliki skor 0,566. Adapun faktor eksternal yang menjadi ancaman paling besar bagi "UD
Mandiri" yaitu adanya pesaing baru dengan skor 0,214 .

\section{Matriks SWOT}

Pada tahap ini, kemudian dilakukan analisis dan penentuan keputusan dengan menggunakan pendekatan matriks SWOT. Matriks tersebut dapat menggambarkan secara jelas bagaimana peluang dan ancaman eksternal yang dihadapi perusahaan dapat disesuaikan dengan kekuatan dan kelemahan internal yang dimilikinya. Selanjutnya, hubungan kedua faktor tersebut diberikan solusi yang menghasilkan berbagai kemungkinan alternatif strategi (SO, WO, ST, WT) untuk formula atau rumusan pengembangan agroindustri dodol salak di desa pangu satu. Adapun analisis dengan pendekatan matriks SWOT ini, dapat dilihat pada tabel 8 .

Tabel 8. Matriks SWOT (Strength, Weakness, Opportunities, Threats)

\begin{tabular}{|c|c|c|}
\hline Eksternal & $\begin{array}{l}\text { Strengths (S) } \\
\text { 1. Proses sortir bahan baku yang } \\
\text { baik. (S1) } \\
\text { 2. Peralatan produksi yang baik } \\
\text { (S2) } \\
\text { 3. Tenaga kerja perusahaan } \\
\text { yang cukup tersedia. (S3) } \\
\text { 4. Produk bebas dari bahan } \\
\text { pengawet dan pewarna. (S4) }\end{array}$ & $\begin{array}{l}\text { Weaknesses (W) } \\
\text { 1. Terbatasnya modal. (W1) } \\
\text { 2. Manajemen yang kurang } \\
\text { terkoordinasi. (W2) } \\
\text { 3. Sumberdaya manusia (SDM) } \\
\text { belum terlatih. (W3) } \\
\text { 4. Tingkat kedisiplinan tenaga } \\
\text { kerja rendah. (W4) }\end{array}$ \\
\hline 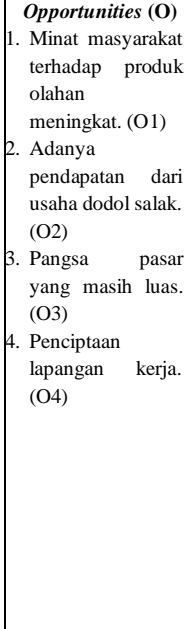 & $\begin{array}{l}\text { Strategi S-O } \\
\text { 1. Perusahaan berupaya mencari } \\
\text { proses sortir bahan baku dan } \\
\text { alat produksi yang lebih baik, } \\
\text { memanfaatkan tenaga kerja } \\
\text { untuk menghasilkan produk } \\
\text { yang unggul sehingga } \\
\text { meningkatkan minat } \\
\text { masyarakat terhadap produk } \\
\text { dodol salak. (S1, S2-O1) } \\
\text { 2. Dengan proses sortir bahan } \\
\text { baku yang baik maka } \\
\text { pengusaha dapat meraih } \\
\text { kesempatan untuk } \\
\text { meningkatkan pangsa pasar } \\
\text { serta pendapatan dari usaha } \\
\text { tersebut. (S1-O2, O3) } \\
\text { 3. Perusahaan menggunakan } \\
\text { produk yang bebas dari bahan } \\
\text { pengawt dan pewarna untuk } \\
\text { menngkatkan manat minat } \\
\text { masyarakat terhadap produk } \\
\text { olahan. (S4-O1) }\end{array}$ & $\begin{array}{l}\text { Strategi W-O } \\
\text { 1. Menambah modal melalui } \\
\text { instansi-instansi terkait } \\
\text { seperti Bank atau instansi } \\
\text { lainnya untuk meningkatkan } \\
\text { pendapatan pengusaha dodol } \\
\text { salak. (W1 - O2) } \\
\text { 2. Mengadakan pelatihan } \\
\text { sumberdaya manusia untuk } \\
\text { meningkatkan proses kerja } \\
\text { perusahaan dan menambah } \\
\text { peluang bagi pengusaha } \\
\text { untuk menciptakan lapangan } \\
\text { kerja baru dan mengurangi } \\
\text { angka pengangguran. (W3 - } \\
\text { O4) }\end{array}$ \\
\hline \begin{tabular}{|l} 
Threats (T) \\
1. Ketersediaan \\
bahan baku yang \\
berfluktuasi. (T1) \\
2. "Pembajakan" \\
tenaga kerja. (T2) \\
3. Adanya pesaing \\
baru. (T3) \\
4. Sarana dan \\
prasarana \\
transportasi yang \\
kurang memadai. \\
(T4)
\end{tabular} & $\begin{array}{l}\text { Strategi S-T } \\
\text { 1. Mempertahankan dan } \\
\text { meningkatkan proses sortir } \\
\text { dan kualitas kesehatan produk } \\
\text { untuk dapat bersaing dengan } \\
\text { perusahaan yang ada (S1, S4 } \\
\text { - T3) } \\
\text { 2. Pengusaha seharusnya } \\
\text { bekerjasama bukan hanya } \\
\text { dengan satu pemasok } \\
\text { (petani). (S1- T1) } \\
\text { 3. Untuk menghindari } \\
\text { "pembajakan" tenaga kerja } \\
\text { maka perusahaan harus } \\
\text { memberikan insentif kepada } \\
\text { tenaga kerja tersebut. (S3-T2) }\end{array}$ & \begin{tabular}{l}
\multicolumn{4}{c}{ Strategi W-T } \\
1. Meningkatkan pendapatan \\
modal untuk mencegah \\
terjadinya pembajakan tenaga \\
kerja dan memanfaatkan \\
modal untuk kegiatan \\
prasarana dan sarana \\
transportasi. $(\mathrm{W} 1-\mathrm{T} 2, \mathrm{~T} 4)$
\end{tabular} \\
\hline
\end{tabular}

Sumber : Hasil Analisis Data SWOT 2017 
Matriks SWOT menghasilkan empat set alternatif strategis yaitu strategi S-O, strategi S-T, strategi W-O dan strategi W-T.

\section{a) Strategi $\mathrm{S}-\mathrm{O}$}

Strategi S-O merupakan strategi yang diterapkan berdasarkan pemanfaatan kekuatan yang dimiliki untuk merebut dan memanfaatkan peluang sebesar-besarnya. Berdasarkan kekuatan yang dimiliki dan peluang yang akan dihadapi oleh agroindustri "UD Mandiri" dapat dirumuskan alternatif strategi yaitu perusahaan berupaya mencari, menciptakan proses sortiran bahan baku yang lebih baik dan mencari alat produksi yang lebih baik serta memanfaatkan tenaga kerja yang ada untuk menghasilkan produk yang unggul sehingga meningkatkan minat atau ketertarikan masyarakat terhadap produk olahan dodol salak (S1, S2 - O1) dan dengan proses sortir pemilihan bahan baku yang baik maka pengusaha dapat meraih kesempatan untuk meningkatkan pangsa pasar serta pendapatan dari usaha tersebut $(\mathrm{S} 1-\mathrm{O} 2, \mathrm{O} 3)$.

\section{b) Strategi $S-T$}

Strategi S-T merupakan strategi yang diterapkan dengan menggunakan kekuatan yang dimiliki perusahaan untuk mengatasi ancaman yang ada. Berdasarkan kekuatan yang dimiliki dan ancaman yang akan dihadapi agroindustri "UD Mandiri" dapat dirumuskan alternatif strategi yaitu mempertahankan dan meningkatkan proses sortir bahan baku dan kualitas kesehatan produk untuk lebih dapat bersaing dengan perusahaan yang ada (S1, S4 - T3), pengusaha seharusnya bekerjasama bukan hanya dengan satu pemasok (petani) (S1 T1), untuk menghindari "pembajakan" tenaga kerja yang ada maka perusahaan harus memberikan insentif kepada tenaga kerja tersebut (S3-O2).

\section{c) Strategi W-O}

Strategi W-O merupakan strategi yang diterapkan berdasarkan pemanfaatan peluang yang ada dengan cara meminimalkan kelemahan yang ada. Berdasarkan kelemahan yang dimiliki dan peluang yang ada pada agroindustri "UD Mandiri" dapat dirumuskan strategi, yaitu menambah modal melalui instansi-instansi terkait seperti Bank atau instansi lainnya untuk meningkatkan pendapatan pengusaha dodol salak (W1 - O2) dan mengadakan pelatihan sumberdaya manusia untuk meningkatkan proses kerja perusahaan dan menambah peluang bagi pengusaha untuk menciptakan lapangan kerja baru dan mengurangi angka pengangguran (W3 - O4)

\section{d) Strategi W-T}

Strategi W-T merupakan strategi yang diterapkan pada kegiatan yang bersifat defensif dan berusaha meminimalkan kelemahan yang ada serta menghindari ancaman. Berdasarkan kelemahan yang dimiliki dan ancaman yang dihadapi agroindustri "UD Mandiri" dapat dirumuskan alternatif strategi yaitu meningkatkan pendapatan modal untuk mencegah terjadinya pembajakan tenaga kerja dan memanfaatkan modal untuk kegiatan prasarana dan sarana transportasi (W1 - T2, T4).

\section{Matriks Grand Strategy (Matriks Posisi)}

Matriks Grand Strategy digunakan untuk mengetahui strategi bisnis yang tepat bagi perusahaan. Dimana, apakah perusahaan ingin memanfaatkan posisi yang kuat atau mengatasi kendala yang ada. Menurut Rangkuti (2015), adapun ide dasar dari strategi ini adalah pemilihan dua variabel sentral di dalam proses penentuan, yaitu Penentuan tujuan utama grand strategy dan Memilih faktor-faktor internal atau eksternal untuk pertumbuhan atau profitabilitas.

Penentuan posisi perusahaan dilakukan dengan cara memadukan variabel kekuatan, kelemahan, peluang dan ancaman yang dimiliki perusahaan sehingga dapat ditentukan titik koordinat dalam diagram SWOT.

Diagram SWOT merupakan diagram yang digunakan untuk menentukan posisi perusahaan dengan cara memadukan kekuatan (strength), kelemahan (weakness), peluang (opportunities) dan ancaman (threat) sehingga dapat ditentukan titik koordinat. 


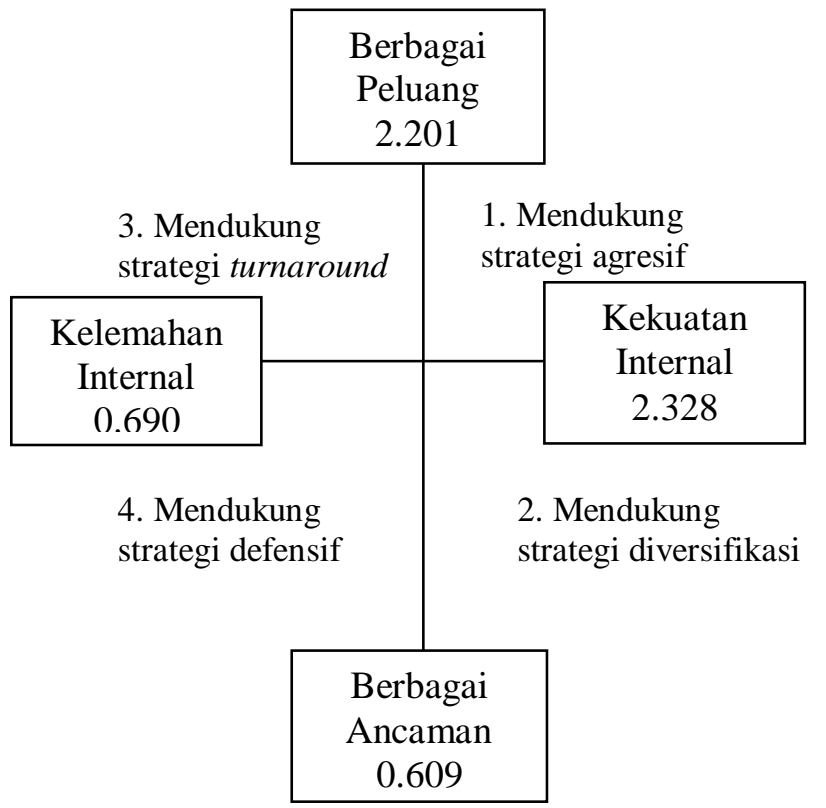

Gambar 2. Diagram Analisis SWOT UD. Mandiri

Berdasarkan gambar dua dapat dilihat titik koordinat $(1,638,1,592)$ yang diperoleh menunjukkan bahwa UD. Mandiri berada pada kuadran I, yaitu posisi perusahaan yang mendukung kebijakan pertumbuhan yang agresif (growth oriented strategy). Posisi ini merupakan situasi yang mengutungkan bagi perusahaan karena memiliki kekuatan dan peluang yang besar yaitu kekuatan dengan jumlah skor 2.328 dan peluang dengan jumlah skor 2.201. Perusahaan dapat menggunakan kekuatan yang ada untuk mencapai peluang.

\section{KESIMPULAN DAN SARAN}

\section{Kesimpulan}

Berdasarkan hasil penelitian yang dilakukan, strategi pengembangan dodol salak di Desa Pangu Satu adalah:

Menerapkan strategi agresif, yaitu dengan menciptakan proses sortiran bahan baku dan peralatan produksi yang lebih baik serta memanfaatkan tenaga kerja untuk menghasilkan produk yang unggul; melalui proses sortir pemilihan bahan baku yang baik untuk meningkatkan pendapatan; perusahaan menggunakan produk yang bebas dari bahan pengawet dan pewarna untuk meningkatkan minat masyarakat terhadap produk olahan; meningkatkan proses sortir bahan baku dan kualitas kesehatan produk untuk lebih dapat bersaing dengan perusahaan yang ada; bekerjasama bukan hanya dengan satu pemasok (petani); menambah modal melalui instansiinstansi terkait seperti Bank atau instansi lainnya; mengadakan pelatihan sumberdaya manusia untuk meningkatkan proses kerja perusahaan dan menambah peluang bagi pengusaha untuk menciptakan lapangan kerja baru dan mengurangi angka pengangguran; meningkatkan pendapatan modal untuk mencegah terjadinya pembajakan tenaga kerja dan memanfaatkan modal untuk kegiatan prasarana dan sarana transportasi.

\section{Saran}

1. Pelaku agroindustri dodol salak di Desa Pangu Satu kecamatan Ratahan, khususnya usaha agroindustri dodol salak "UD Mandiri" perlu menerapkan strategi agresif berupa perusahaan mencari dan menciptakan proses sortiran bahan baku, peralatan kerja yang lebih baik serta memanfaatkan tenaga kerja untuk menghasilkan produk yang unggul sehingga meningkatkan minat masyarakat terhadap produk dodol salak, pengusaha dapat meraih kesempatan dalam meningkatkan pagsa pasar serta pendapatan dengan proses pemilihan bahan baku yang lebih baik, perusahaan menggunakan produk yang bebas dari bahan pengawet dan pewarna untuk meningkatkan minat masyarakat terhadap produk dodol salak.

2. Menjalin kerjasama dengan pemerintah dan penyuluhan pertanian untuk mengembangkan strategi dodol salak dengan kualitas sumberdaya yang baik, menjalin kerjasama dengan perbankan guna meningkatkan pendapatan, dan mempertahankan proses sortiran bahan baku yang lebih baik guna menarik minat konsumen terhadap produk olahan dodol salak.

\section{DAFTAR PUSTAKA}

Austin, J. E., 1981. Agroindustrial Projeck Analysis. The John Hopkins University Press. London. 
Budiarto, S., 2011. Pemasaran Industri (Business to Business Marketing). C.V Andi Offset, Yogyakarta

Danang, S., 2013. Perilaku Konsumen (Panduan Riset Sederhana Untuk Mengenali Konsumen). CAPS (Center Of Academic Publishing Service), Yogyakarta.

Hardyanto W, 1991. Prospek Pengembangan Agroindustri Dalam Pembangunan Pedesaan Bag. 3. E Petani (Elektronik Petani).

Kesatria, T.F. 2002. Analisis Strategi Pemasaran Ekspor Teh Hitam Pada Kantor Pemasaran Bersama (KPB) PT Perkebunan Nusantara. Institut Pertanian Bogor.

Kuncoro, Mudrajad. 2005. Strategi (Bagaimana Meraih Keunggulan Kompetitif). Jakarta: Penerbit Erlangga

LAN-RI (Lembaga Administrasi NegaraRepublik Indonesia), 2008. Konsep Strategi Pengembangan. Membingkai Teori Menjadi Tesis.

Manurung, V. H., G. S. S. Djarkasi, Dan L. E. Lalujan. 2008. Analisis Sifat Fisik Dan Kimia Buah Salak Pangu (Salacca Zalacca) Dengan Pelilinan Selama Penyimpanan. Fakultas Pertanian Unsrat. Manado

Philip Kotler. 1992. Manajemen Pemasaran (Terjemahan), Jilid I, edisi kelima. Erlangga. Jakarta.

Rangkuti, Freddy., 2006. Analisis SWOT Teknik Membedah Kasus Bisnis. PT Gramedia Pustaka Utama. Jakarta.

Rangkuti F, 2008. Analisis SWOT: Teknik Membedah Kasus Bisnis. PT Gramedia Pustaka Utama, Jakarta.
Rangkuti, F. 2015. Analisis SWOT: Teknik Membedah Kasus Bisnis. Gramedia Pustaka Utama. Jakarta

Soetomo, H. 2001. Teknik Bertanam Salak. Sinar Baru. Bandung.

Soekartawi. 2005. Pembangunan Pertanian Pertanian Indonesia. PT. Raja Grafindo Persada. Jakarta

Sondakh, J., Novarianto, R., and Mantau, Z. 2008. Analisis Kinerja Pembangunan Pertanian Pedesaan Di Sulawesi Utara. Balai Pengkajian Teknologi Pertanian (BPTP) Sulawesi Utara J1. Kampus Pertanian Kalasey, Sulut.

Sugiarto, Ulfa H., 2012. Skripsi, Analisis Keuangan Agroindustri Keripik Singkong "Kita Suka Dua Putra" di kecamatan Malalayang. Universitas Sam Ratulangi, Fakultas Pertanian, Jurusan Sosial Ekonomi, Manado.

Simatupang, 1989. Integrasi harga ubikayu dan gaplek di lampung. Forum Statistik 8 (1): 21-28.

Tarigan, H dan Ariningsih, E., 2007. Peluang dan Kendala Pengembangan Agroindustri Sagu di Kabupaten Jayapura.

Yanuaria, L.W. 2012. Strategi PT Kereta Api Indonesia (KAI) Dalam Meningkatkan Pelayanan Transportasi Kereta Api. Universitas Negeri Yogyakarta.

William J. S,. 1991. Prinsip Pemasaran, edisi ketujuh, jilid 1. Erlangga. Jakarta. 